\title{
Concomitant SARS-CoV-2 infection and severe neurologic involvement in a late-preterm neonate
}

Paola Di Nicola, MD, Simone Ceratto, MD, Cristina Dalmazzo, MD, Luca Roasio, MD, PhD, Elio Castagnola, MD, PhD, and Andrea Sannia, MD, PhD

Neurology ${ }^{\circledR}$ 2020;95:834-835. doi:10.1212/WNL.0000000000010729

SARS-CoV-2 is recognized as the cause of the coronavirus disease 2019 (COVID-19) pandemic. COVID-19 is less frequent and severe in children, with few cases reported in newborns. ${ }^{1,2}$

An 18-day-old girl, born at $35^{+1}$ week of postmenstrual age in another center from a diamniotic monochorionic twin pregnancy through spontaneous delivery, was admitted in the neonatal intensive care unit of S. Croce e Carle Hospital, Cuneo, Italy, because of decreased oral intake, mild respiratory distress, and conjunctivitis. She was discharged home clinically well 5 days after birth from a center where COVID-19 pregnant women were treated. Family history was unremarkable, and her mother was not tested for SARS-CoV-2 infection at delivery. At the time of admission, she was drowsy with mild respiratory distress. Treatment with high-flow nasal cannulas was initiated, but she was subsequently intubated and mechanically ventilated because of impending episodes of apnea. In the following hours, the patient developed sudden signs of encephalopathy: she became lethargic and alert state was not maintained. Primitive reflexes were not elicitable, with general hypotonia, absence of spontaneous movements, and pain response, but pupils were reactive to light. No spontaneous breathing was detected during synchronized mechanical ventilation for 48 consecutive hours in the absence of pharmacologic sedation. At this time, she presented leukopenia (white blood cells 2,770/ $\mu \mathrm{L}$ ) and slightly increased of aspecific inflammatory indices (C-reactive protein $12.6 \mathrm{mg} / \mathrm{L}$, procalcitonin $1.31 \mathrm{ng} / \mathrm{mL}$ ); the chest $\mathrm{x}$-ray showed no lung infiltration and abdominal overdistention. Urine and blood cultures were negative. SARS-CoV-2 and Hemophilus influenzae were detected in the nasopharynx and bronchoalveolar lavage samples by PCR. At this time, all family members, always asymptomatic, were screened for SARS-CoV-2: the mother, 2 brothers, and grandmother resulted positive, whereas the father and the twin brother resulted negative. The CSF examination showed 12 cells $/ \mu \mathrm{L}$, with glucose $71 \mathrm{mg} / \mathrm{dL}$, and the microbiological investigation was negative, including SARS-CoV-2 research. Broad-spectrum empirical antimicrobial therapy was started. Supportive treatment including oxygen supplementation and the maintenance of water-electrolyte and acid-base homeostasis was continued. Intravenous caffeine was administered as respiratory analeptic. Serial transfontanellar ultrasounds performed from day 1 to day 3 showed no pathologic images. An EEG showed cortical depression without seizures. After 48 hours, the patient became more reactive with a rapid clinical improvement. Spontaneous antigravity movements, primitive reflexes, and initial spontaneous breathing during assisted ventilation were observed. On day 4, she was extubated. Vital signs were within the normal range, and she breathed spontaneously. MRI showed no abnormalities on conventional sequences ( $\mathrm{T} 1$ and $\mathrm{T} 2$ weighted) and no restricteddiffusion abnormalities on the diffusion-weighted image and apparent diffusion coefficient map.

In this 18-day-old late-preterm neonate, severe neurologic impairment occurred in the presence of SARS-CoV-2 infection and of mild symptoms attributable to COVID-19 (conjunctivitis and mild respiratory distress). CSF and MRI were normal, and SARS-CoV-2 was detected only in the respiratory tract, together with $H$. influenzae. This pathogen can be a cause of sepsis and meningitis in newborns, ${ }^{3}$ but in our patient, clinical and imaging features were completely normal, and the pathogen was not detected both in the blood and CSF. Bacterial and SARSCoV-2 coinfections have been described in pediatrics, without any worsening of the clinical
Correspondence

Dr. Castagnola

eliocastagnola@gaslini.org

MORE ONLINE

COVID-19 Resources

For the latest articles, invited commentaries, and blogs from physicians around the world NPub.org/COVID19

From the Neonatal Intensive Care Unit (P.D.N., C.D., A.S.), S. Croce e Carle Hospital, Cuneo, Italy; Postgraduation School of Pediatrics (S.C.), University of Turin, Torino, Italy; Department of Pediatrics (L.R.), “E. Agnelli” Hospital, Pinerolo, Italy; and Infectious Diseases Unit (E.C.), IRCCS Istituto Giannina Gaslini, Genova, Italy.

Go to Neurology.org/N for full disclosures. Funding information and disclosures deemed relevant by the authors, if any, are provided at the end of the article. 
picture. ${ }^{1,2,4}$ Therefore, because no other reliable cause of the clinical picture was observed, a strong suspicion of an association between the encephalopathy and SARS-CoV-2 infection still remains.

Few data are available for SARS-CoV-2 infection in neonates, and the clinical pictures described in the literature are mainly respiratory or gastrointestinal disease associated with fever, ${ }^{1,2,4}$ with rare neurologic manifestations, including lethargy reported also in neonates. Nothing similar to was observed in our patient is described. ${ }^{1,2,4}$ Neurologic manifestations have been observed in adults with COVID-19 that could play a role in the respiratory failure of these patients. ${ }^{5,6}$ It is known that the brainstem of late-preterm infants $\left(34-36^{+6}\right.$ weeks of postmenstrual age) is less mature than that of a full-term infant ${ }^{7}$ and that in preterm newborns, brain stem maturation is not linear, as well as that of upper airway and lung volume control, laryngeal reflexes, chemical control of breathing, and sleep mechanisms. ${ }^{7}$ Therefore, it is possible that the cortical depression observed at the EEG was due to hypersomnia related to a possible, transient involvement of the ascending reticular substance at the brainstem level. Considering the described neurotropism of SARS$\mathrm{CoV}-2$, it is conceivable that a (late)-preterm infant could be at risk of neurologic involvement with respiratory failure of central origin, even several days after birth. This should be kept in mind by the neonatologists in an era of SARS-CoV-2 pandemic.

\section{Study funding}

No targeted funding reported.

\section{Disclosure}

The authors report no conflicts of interest relevant to the manuscript. Go to Neurology.org/N for full disclosures.

\section{Publication history}

Received by Neurology May 9, 2020. Accepted in final form August 13, 2020.

\begin{tabular}{|c|c|c|}
\hline Name & Location & Contribution \\
\hline $\begin{array}{l}\text { Paola Di } \\
\text { Nicola, MD }\end{array}$ & $\begin{array}{l}\text { Neonatal Intensive Care } \\
\text { Unit, S. Croce e Carle } \\
\text { Hospital, Cuneo, Italy }\end{array}$ & $\begin{array}{l}\text { Patient evaluation and } \\
\text { data collection and } \\
\text { manuscript preparation }\end{array}$ \\
\hline $\begin{array}{l}\text { Simone } \\
\text { Ceratto, MD }\end{array}$ & $\begin{array}{l}\text { Postgraduation School of } \\
\text { Pediatrics, University of } \\
\text { Turin, Torino, Italy }\end{array}$ & $\begin{array}{l}\text { Patient evaluation and } \\
\text { data collection and } \\
\text { manuscript revision }\end{array}$ \\
\hline $\begin{array}{l}\text { Cristina } \\
\text { Dalmazzo, } \\
\text { MD }\end{array}$ & $\begin{array}{l}\text { Neonatal Intensive Care } \\
\text { Unit, S. Croce e Carle } \\
\text { Hospital, Cuneo, Italy }\end{array}$ & $\begin{array}{l}\text { Patient evaluation and } \\
\text { data collection and } \\
\text { manuscript revision }\end{array}$ \\
\hline $\begin{array}{l}\text { Luca } \\
\text { Roasio, MD, } \\
\text { PhD }\end{array}$ & $\begin{array}{l}\text { Department of Pediatrics, } \\
\text { “E. Agnelli" Hospital, } \\
\text { Pinerolo, Italy }\end{array}$ & $\begin{array}{l}\text { Patient evaluation and } \\
\text { data collection and } \\
\text { manuscript revision }\end{array}$ \\
\hline $\begin{array}{l}\text { Elio } \\
\text { Castagnola, } \\
\text { MD, PhD }\end{array}$ & $\begin{array}{l}\text { Infectious Diseases Unit, } \\
\text { IRCCS Istituto Giannina } \\
\text { Gaslini, Genova, Italy }\end{array}$ & $\begin{array}{l}\text { Clinical data analysis and } \\
\text { pathophysiologic } \\
\text { interpretation and paper } \\
\text { revision }\end{array}$ \\
\hline $\begin{array}{l}\text { Andrea } \\
\text { Sannia, MD, } \\
\text { PhD }\end{array}$ & $\begin{array}{l}\text { Neonatal Intensive Care } \\
\text { Unit, S. Croce e Carle } \\
\text { Hospital, Cuneo, Italy }\end{array}$ & $\begin{array}{l}\text { Patient evaluation, clinical } \\
\text { data analysis and } \\
\text { pathophysiologic } \\
\text { interpretation, and paper } \\
\text { revision }\end{array}$ \\
\hline
\end{tabular}

\section{References}

1. Di Nardo M, van Leeuwen G, Loreti A, et al. A literature review of 2019 novel coronavirus (SARS-CoV2) infection in neonates and children. Pediatr Res 2020. doi: $10.1038 /$ s41390-020-1065-5

2. Deniz $\mathrm{M}$, Tezer H. Vertical transmission of SARS CoV-2: a systematic review. J Matern Fetal Neonatal Med 2020:1-8. doi: 10.1080/14767058.2020.1793322.

3. Nizet V, Klein JO. Bacterial Sepsis and Meningitis. In: Wilson CB, Nizet V, Maldonado YA, Remington KS, Klein JO, EDS:Remington \& Klein's Infectious Diseases of thefetus and newborn infant. Philadelphia: Elsevier; 2016: 271.

4. Castagnoli R, Votto M, Licari A, et al. Severe acute respiratory syndrome coronavirus 2 (SARS-CoV-2) infection in children and adolescents: a systematic review. AMA Pediatr 2020. doi: 10.1001/jamapediatrics.2020.1467.

5. Baig AM. Neurological manifestations in COVID-19 caused by SARS-CoV-2. CNS NeurosciTher 2020;26:499-501.

6. Li YC, Bai WZ, Hashikawa T. The neuroinvasive potential of SARS-CoV2 may play a role in the respiratory failure of COVID-19 patients. J Med Virol 2020. doi: 10.1002/jmv.25728.

7. Darnall RA, Ariagno RL, Kinney HC. The late preterm infant and the control of breathing, sleep, and brainstem development: a review. ClinPerinatol 2006;33:883-914.

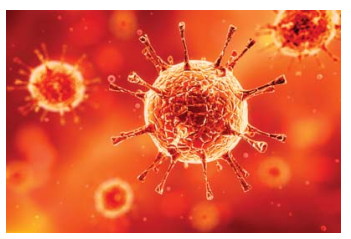

\section{COVID-19 and Neurologic Disease: Call for Papers!}

The editors of Neurology are interested in papers that address the neurological aspects of COVID-19 infection and challenges to the management of patients with chronic neurological conditions who have, or are at risk for, the infection. Relevant papers that pass initial internal review will undergo expedited peer review and online publication. We will consider papers posted in preprint servers.

Submit observational studies and clinical trials as Articles and case series and case reports under the Clinical/Scientific Notes category to https://submit.neurology.org/ today! 


\section{Neurology}

\section{Concomitant SARS-CoV-2 infection and severe neurologic involvement in a late-preterm neonate}

Paola Di Nicola, Simone Ceratto, Cristina Dalmazzo, et al. Neurology 2020;95;834-835 Published Online before print September 15, 2020 DOI 10.1212/WNL.0000000000010729

This information is current as of September 15, 2020

\section{Updated Information \&} Services

References

Subspecialty Collections

Permissions \& Licensing

Reprints including high resolution figures, can be found at: http://n.neurology.org/content/95/18/834.full

This article cites 6 articles, 0 of which you can access for free at: http://n.neurology.org/content/95/18/834.full\#ref-list-1

This article, along with others on similar topics, appears in the following collection(s):

Neonatal

http://n.neurology.org/cgi/collection/neonatal

Information about reproducing this article in parts (figures,tables) or in its entirety can be found online at:

http://www.neurology.org/about/about_the_journal\#permissions

Information about ordering reprints can be found online:

http://n.neurology.org/subscribers/advertise

Neurology ${ }^{\circledR}$ is the official journal of the American Academy of Neurology. Published continuously since 1951, it is now a weekly with 48 issues per year. Copyright @ 2020 American Academy of Neurology. All rights reserved. Print ISSN: 0028-3878. Online ISSN: 1526-632X.

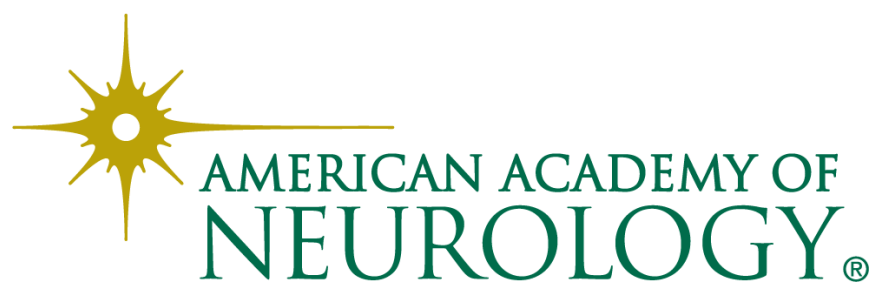

